\title{
In-vitro Antioxidant and Antimicrobial Activities of Some Medicinal Plants grown in Western Ghats of India
}

\author{
N. Vijaya Sree ${ }^{1}$, P.Udaya $\mathrm{Sri}^{2}$, Y.V.V. Aswani $\mathrm{Kumar}^{3} \&$ N. RamaRao \\ ${ }^{1-3}$ (Department of Biotechnology, Acharya Nagarjuna University, Guntur-522510, Andhra Pradesh, India) \\ ${ }^{4}$ (Principal, Chalapathi Institute of Pharmaceutical Sciences, Lam, Guntur-34, Andhra Pradesh, India)
}

\begin{abstract}
The aim of the study was to evaluate medicinal potential of five mostly used plants from Western Ghats of India. Methanolic, aqueous and ethylaceate extracts of the plant species were screened for its total phenolic, flavonoid contents, in-vitro antioxidant and, antimicrobial activities against pathogenic bacterial and fungal species. Minimal inhibitory concentration (MIC) of the extracts were determined by disc diffusion method. Free radical scavenging activity was evaluated using 1,1-diphenyl-2-picryl hydrazyl (DPPH) free radical. The overall antioxidant activity of Narvelia zeylanica and Adathoda zeylancia were found to be the strongest, the $\mathrm{IC}_{50}$ values of the extracts ranged between $3.12 \mu \mathrm{g} / \mathrm{ml}$ to $15.3 \mu \mathrm{g} / \mathrm{ml}$. The tested plant extracts presented a remarkable capacity total antioxidant capacity equivalent to vitamin $\mathrm{C}$ being, The same extracts were shown to have the highest phenolic and flavonoid values. The total phenol and flavonoid levels varied from $9 \pm 0.32$ to $24 \pm 0.03 \mathrm{mg} \mathrm{CE} / \mathrm{g} \mathrm{dw}$ and $5.32 \pm 0.65$ to $18.2 \pm 0.21 \mathrm{mg} \mathrm{GAE} / \mathrm{g} \mathrm{dw}$, respectively. Many of the extracts showed activity against pathogenic/toxigenic bacteria and fungal strains. The present study reveals that the selected plants would exert several beneficial effects by virtue of their antioxidant activity and antimicrobial activity, and could be harnessed as drug formulation.
\end{abstract}

Key words: Anti-oxidant activity, Anti bacterial activity, Anti fungal activity, DPPH, Phenolics

\section{INTRODUCTION}

Medicinal plants are a source for a wide variety of natural antioxidants. In the study reported here, we have conducted a comparative study among seven medicinal plants originated from the same geographic origin, the Western Ghats region in India and growing in the same natural conditions. Phenolic compounds which are secondary metabolites in plants are one of the most widely occurring groups of phytochemicals that exhibit antiallergenic, antimicrobial, antiartherogenic, antithrombotic, antiinflammatory, vasodilatory and cardioprotective effects [1]. Due to the presence of the conjugated ring structures and hydroxyl groups; many phenolic compounds have the potential to function as antioxidants by scavenging or stabilizing free radicals involved in oxidative processes through hydrogenation or complexing with oxidizing species that are much stronger than those of vitamins $\mathrm{C}$ and $\mathrm{E}$ [2]. With increasing recognition of herbal medicine as an alternative form of health care, screening of medicinal plants for biologically active compounds has become an important source of antibiotic prototypes and cancer-related drugs [3]. Hence, for selecting crude plant extracts with potential useful properties, in vitro screening methods have been used for further in-depth chemical elucidation and pharmacological investigations.

It has been established that oxidative stress is among the major causative factors in induction of many chronic and degenerative diseases including atherosclerosis, ischemic heart disease, ageing, diabetes mellitus, cancer, immunosuppression, neurodegenerative diseases and others [4]. A great number of aromatic, medicinal, spice and other plants contain chemical compounds exhibiting antioxidant properties. Oxidative process is one of the most important routes for producing free radicals in foods, drugs and even in living systems [5]. The most effective path to eliminate and diminish the action of free radicals which cause the oxidative stress is antioxidative defense mechanisms. Antioxidants are those substances which possess free radical chain reaction breaking properties. Among the numerous naturally occurring antioxidants; ascorbic acid, carotenoids and phenolic compounds are more effective [6]. They are known to inhibit lipid peroxidation (by inactivating lipoxygenase), to scavenge free radicals and active oxygen species by propagating a reaction cycle and to chelate heavy metal ions [7].

Oxidative stress is mediated by reactive oxygen species (ROS) which are generated during the normal and aberrant cellular metabolism that utilizes molecular oxygen. The adverse effects of oxidative stress on human health have become a serious issue. The World Health Organization (WHO) has estimated that $80 \%$ of the earth's inhabitants rely on traditional medicine for their primary health care needs, and most of this therapy involves the use of plant extracts and their active components. Under stress, body produces more reactive oxygen species (ROS) (e.g., superoxide anion radicals, hydroxyl radicals and hydrogen peroxide) than 
enzymatic antioxidants (e.g., superoxide dismutase (SOD), glutathione peroxidase (GPx), catalase and nonenzymatic antioxidants viz. ascorbic acid (vitamin C), $\alpha$-tocopherol (vitamin E), glutathione, carotenoids, and flavonoids. Imbalance of reactive oxygen species leads to cell cytotoxicity [8-12] and health disorders [13, 14]. A lack of antioxidants, which can quench the reactive free radicals, facilitates the development of degenerative diseases like cardiovascular diseases, cancers [15], neurodegenerative diseases, Alzheimer's disease [16] and inflammatory diseases [17]. One solution to this problem is to supplement the diet with antioxidant compounds that are contained in natural plant sources [18]. These natural plant antioxidants can therefore serve as a type of preventive medicine.

Recent reports indicate that there is an inverse relationship between the dietary intake of antioxidantrich foods and the incidence of human disease [19]. The health-promoting effect of antioxidants from plants is thought to arise from their protective effects by counteracting reactive oxygen species (ROS) [20]. Antioxidants, including phenolic compounds (e.g., flavonoids, phenolic acids and tannins), have diverse biological effects, such as anti-inflammatory, anti-carcinogenic and antiatherosclerotic effects, as a result of their antioxidant activity [21]. The antioxidant extracts were evaluated in terms of their total phenols (TP), total flavonoids (TFA), total flavonols (TFO), phenolic acids, catechins, lignans and tannins [22, 23].

During the past several years, there has been an increasing incidence of bacterial and fungal infections due to an unprecedent growth of population and improper food habits and also increment in immunocompromised population such as organ transplant recipients, cancer and HIV/AIDS patients. This fact coupled with the resistance to antibiotics and with the toxicity during prolonged treatment with several anti bacterial and antifungal drugs [24] has been the reason for an extended search for newer drugs to treat bacteria and fungal infections [25]. Due to the increasing development of drug resistance in human pathogens as well as the appearance of undesirable effect of certain antimicrobial agents, there is a need to search new antifungal agent without toxicity and side effect.

Plant extracts or plant-derived compounds are likely to provide a valuable source of new medicinal agents $[26,27]$. Infectious diseases are common in most of the tribal inhabitants due to lack of sanitation, potable water and awareness of hygienic food habits. Important groups of these pathogens are mainly food born bacteria and fungi. Antimicrobial properties of certain Indian medicinal plants were reported based on folklore information [28-35], and a few attempts were made on inhibitory activity against certain pathogenic bacteria and fungi.

The purposes of this study were to determine the content of total phenolics and total flavonoids and to evaluate total antioxidant activity, free radical scavenging activity, and to determine the antimicrobial activity of five Indian medicinal plants of Western Ghats.

\subsection{Chemicals}

\section{MATERIALS AND METHODS}

1,1-Diphenyl-2-picrylhydrazyl (DPPH), 2-deoxyribose, 2,2'-azino-bis-3-ethylbenzthiazoline-6sulphonic acid (ABTS), 2,2'-azobis(2-amidinopropane) dihydrochloride (AAPH), ascorbic acid, (+)-catechin, copper sulphate $\left(\mathrm{CuSO}_{4}\right)$, ferrous sulphate, ferrozine, Folin-Ciocalteu's reagent, gallic acid, hydrochloric acid $(\mathrm{HCl})$, sodium carbonate, sodium hydroxide were purchased from Sigma-Aldrich (St. Louis, MO). Ethyl acetate and HPLC grade methanol were purchased from Merck (Mumbai, India).

\subsection{Apparatus}

Microplate spectrophotometer (PowerWaveX, Bio-Tek instruments, Inc., USA) was used to record the absorbance of in vitro antioxidant test systems and phytochemical content assays. Fluorescence microplate reader (FLx800, Bio-Tek instruments, Inc., USA) was used to record the fluorescence intensity in hydrogen peroxide-scavenging activity assay.

\subsection{Collection of plant material}

Five mostly used plants such as Naravelia zeylanica DC., Adhathoda zeylanica Medic, Cassia auriculata L, Vitex negundo L, Orthosiphon staminus., of Western Ghats were collected on the basis of ethnobotanical survey in June - August 2012. Plant specimens were identified by Department of Pharmacognosy, Chalapathi Institute of Pharmaceutical Sciences, Acharya Nagarjuna University, India. Voucher specimens were deposited in the same institute.

\subsection{Extraction of plant material}

Air dried plant materials were extracted with methanol, ethyl aceate and water seperatly by using Soxhlet apparatus. The filtrates were evaporated under reduced pressure and lyophilized (Hitachi, USA). The lyophilized plant extracts were further analysed for antioxidant and antimicrobial assays. 


\subsection{Determination of Total Phenolics and flavanoids}

Phenolic contents were evaluated by using Folin-Ciocalteu reagent [36]. Total phenolic contents in medicinal plants were expressed as mg gallic acid equivalents (GAE)/g dry weight. Total flavonoid contents were measured according to a colorimetric assay described by Zhishen, et al. [37] and the results were expressed as mg catechin equivalents $(\mathrm{CE}) / \mathrm{g}$ dry weight $(\mathrm{dw})$.

\subsection{DPPH radical-scavenging effect}

The free radical scavenging activity of the fenugreek extract was determined in vitro by DPPH $(1,1$ diphenyl 2, picryl hydrazyl) assay [38]. DPPH in methanol $(0.1 \mathrm{mM})$ was prepared and $3.0 \mathrm{ml}$ of this solution was added to $40 \mu \mathrm{l}$ of extract solution in water at different concentrations. The mixture was incubated at room temperature for 30 minutes and the absorbance was measured at $515 \mathrm{~nm}$ against corresponding blank solution. Percentage inhibition of DPPH free radical was calculated based on the control reading using the following equation:

$$
\text { DPPH Scavenged }(\%)=\left[\mathrm{A}_{\text {cont }}-\mathrm{A}_{\text {sample }}\right] / \mathrm{A}_{\text {cont }} \times 100
$$

Where $\mathrm{A}_{\text {cont }}$ is the absorbance of the control reaction and $\mathrm{A}_{\text {sample }}$ is the absorbance in the presence of the extract/ standard. The antioxidant activity of the extract was expressed as $\mathrm{IC}_{50}$, which the concentration $(\mu \mathrm{g} / \mathrm{ml})$ of extract inhibits formation of DPPH radicals by $50 \%$.

\subsection{Quantification of Total Antioxidant Activity}

Total antioxidant activity of the samples were determined by Kim et al. [36]. The relative activity of antioxidants to scavenge the ABTS radicals and compared with the standard antioxidant potency of Vitamin C. Total antioxidant activities of medicinal plants were determined by scavenging blue-green ABTS radicals and were expressed as $\mathrm{mg}$ vitamin $\mathrm{C}$ equivalent (VCE) per gm dry weight.

\subsection{Screening for the Antimicrobial potential of the plant extracts}

\subsubsection{Anti bacterial activity}

The antibacterial activity of the extracts was tested on human pathogenic organisms of Gram-positive and Gram-negative bacterial strains. The two Gram-positive bacterial strains used were Methicillin resistant Staphylococcus aureus, Bacillus cereus (DFR-217), and seven Gram-negative bacterial strains used were, Escherichia coli (DFR-13), Klebsiella pneumonia (DFR-327), Shigella flexneri (DFR-526), Pseudomonas aeruginosa (MTCC-1430), Salmonellal typhimurium (MTCC-98), Aeromans hydrophila, Proteus vulgaris (MTCC-1), Listeria monocytogenis, Vibrio cholera and vibrio parahaemolyticus. All bacterial strains were obtained from the DFRL, India/ IMTECH, India. All test bacterial strains were purified by streaking and reisolating three successive times on Muller Hinton Agar (MHA). Each of the microorganisms was reactivated prior to susceptibility testing by transferring them into a separate test tube containing Muller Hinton broth and incubated overnight at $37{ }^{\circ} \mathrm{C}$.

Anti bacterial asses were determined by disc diffusion test and micro-dilution assay [39]. The inoculums size of each test strain was standardized at $5 \times 10^{5} \mathrm{CFU} / \mathrm{ml}$ using McFarland Nephelometer. Suspension containing bacteria was spread on Muller Hinton Agar (MAH) medium. Sterile disc of $6 \mathrm{~mm}$ diameter were impregnated with $20 \mu \mathrm{l}$ of the different concentrations of extract solution. The paper discs were dried and placed on the surface of the inoculated agar plates. Plates were kept for $1 \mathrm{~h}$ in refrigerator to enable pre-diffusion of the extracts into the agar. Then the inoculated plates with pathogenic /toxigenic bacteria were incubated at $37{ }^{\circ} \mathrm{C}$ for overnight to allow to bacterial growth. Tetracycline and gentamicin were used as positive controls. Whereas negative controls were performed with paper discs loaded with $20 \mu \mathrm{l}$ of solvents (methanol, ethyl acetate and water alone) and dried. The anti bacterial activities of the extracts were evaluated by measuring the inhibition zones.

\subsubsection{Antifungal activity}

A total of 12 fungal cultures were used to test the anti fungal activity of the selected plant extracts. Aspergillus flavus (Aflatoxigenic, pathogenic), A. paraciticus (toxigenic), A. niger (pathogenic), A. ochraceus (toxigenic), Penicillium verrucosum (toxigenic), P. norodicum (toxigenic), P. expansum (toxigenic), Fusarium graminearum (toxigenic), F. solani (pathogenic), F. verticillioides (toxigenic, pathogenic), $F$. oxysporum (pathogenic), F. sprorotrichioides and Candida albicans (pathogenic). All fungal strains were obtained from the DFRL, India. Nystatin was used as a positive control. Whereas negative controls were performed with paper discs loaded with methanol/water. The anti fungal activities of the extracts were evaluated by measuring the inhibition zones. After $48 \mathrm{~h}$ of incubation, minimum inhibitory concentration (MIC) values were recorded as the lowest concentrations that inhibited fungal growth. 


\subsection{Total phenolics and flavanoids}

\section{RESULTS}

The amount of total phenolic content (TPC) was expressed as mg GAE/g dry weight in Table -1. The results varied widely among plant samples and the preparation of the extract and ranged from $27 \pm 0.02 \mathrm{mg} \mathrm{CE} / \mathrm{g}$ $\mathrm{dw}$ (Vitex negundo L. methanol extract) to $9 \pm 0.32 \mathrm{mg} \mathrm{CE} / \mathrm{g} \mathrm{dw}$ (ethylaceate extract of Cassia auriculata L.). Total flavanoids were observed in a range from $18.2 \pm 0.21 \mathrm{mg} \mathrm{GAE} / \mathrm{g} \mathrm{dw}$ in methanol extract of Vitex negundo L. to $5.32 \pm 0.65 \mathrm{mg} \mathrm{GAE} / \mathrm{g} \mathrm{dw}$ in ethylaceate extract of Cassia auriculata L.(Table-1).

\subsection{DPPH Radical-Scavenging Activity}

The antioxidant potential is inversely proportional to $\mathrm{IC}_{50}$ value, which were calculated from the linear regression of the \% antioxidant activity versus extracts concentrations. Results shown in Fig. (1) indicate that the water extracts of Adathoda zeylanica Medic and Naravelia zeylanica DC. were recorded has more significant activity.

\subsection{Total anti oxidant capacity}

To express the antioxidant capacity of selected plant extracts in a more familiar and easily understood manner, $\operatorname{ABTS}(*)(-)$ radical species used for study and the antioxidant activities were expressed as vitamin $\mathrm{C}$ equivalent antioxidant capacity (VCEAC) in $\mathrm{mg} / \mathrm{g}$ wt. The results reveals that a range starting from $15 \pm 0.21$ $\mathrm{mg} \mathrm{VCE} / \mathrm{gm} \mathrm{dw}$ to $48 \pm 0.36 \mathrm{mg} \mathrm{VCE} / \mathrm{gm} \mathrm{dw}$ in water extract of Naravelia zeylanica DC. and Orthosiphon staminus methanolic extract respectively. The results of different plant extracts were given in Table-1.

\subsection{Anti microbial activity}

A total of 15 extracts from 5 different plant species were investigated. Extracts of the different solvents of the tested medicinal plants used in this study were shown in Table-2. The Antibacterial susceptibility by means of disk diffusion method showed that the 5 plant extracts tested exhibited an antimicrobial effect against Staphylococcus aureus, Bacillus cereus, Escherichia coli, Klebsiella pneumonia, Shigella flexneri, Pseudomonas aeruginosa, Salmonellal typhimurium, Aeromans hydrophila, Proteus vulgaris, Listeria monocytogenis Vibrio cholera, V. parahaemolyticus (Table 2). Anti fungal activities of the same plant extracts were given in Table-3. All the studied plant extracts have showed positive activity against the fungal pathogens except the water extracts of Vitex negundo L. and Orthosiphon staminus.

Table-1: Estimation of total phenolics, flavonoids and antioxidant activity of plant extracts from Western Ghats of India.

\begin{tabular}{|c|c|c|c|c|c|}
\hline $\mathrm{S}$ No & Plant Name & Extract & $\begin{array}{c}\text { Total } \\
\text { flavanoids } 1\end{array}$ & $\begin{array}{c}\text { Total } \\
\text { phenolics }^{2}\end{array}$ & $\begin{array}{c}\text { Total anti oxidant } \\
\text { activity }^{3}\end{array}$ \\
\hline \multirow[b]{3}{*}{1} & \multirow[b]{3}{*}{ Naravelia zeylanica DC. } & Meoh & $14.8 \pm 0.21$ & $15 \pm 0.07$ & $25 \pm 0.09$ \\
\hline & & Water & $6.2 \pm 0.25$ & $10 \pm 0.37$ & $15 \pm 0.21$ \\
\hline & & Etoa & $12.3 \pm 0.37$ & $14 \pm 0.28$ & $25 \pm 0.34$ \\
\hline \multirow[b]{3}{*}{2} & \multirow{3}{*}{$\begin{array}{l}\text { Adhathoda zeylanica } \\
\text { Medic. }\end{array}$} & Meoh & $17.8 \pm 0.03$ & $19 \pm 0.03$ & $29 \pm 0.65$ \\
\hline & & Water & $9.5 \pm 0.02$ & $12 \pm 0.45$ & $18 \pm 0.25$ \\
\hline & & Etoa & $7.2 \pm 0.11$ & $11 \pm 0.56$ & $21 \pm 0.65$ \\
\hline \multirow[b]{3}{*}{3} & \multirow[b]{3}{*}{ Cassia auriculata $\mathbf{L}$. } & Meoh & $16.86 \pm .21$ & $20 \pm 0.78$ & $32 \pm 0.63$ \\
\hline & & Water & $5.32 \pm 0.65$ & $10 \pm 0.23$ & $23 \pm 0.32$ \\
\hline & & Etoa & $6.4 \pm 0.52$ & $9 \pm 0.32$ & $18 \pm 0.65$ \\
\hline \multirow[b]{3}{*}{4} & \multirow[b]{3}{*}{ Vitex negundo $\mathrm{L}$. } & Meoh & $18.2 \pm 0.21$ & $27 \pm 0.02$ & $27 \pm 0.87$ \\
\hline & & Water & $9.8 \pm 0.56$ & $12 \pm 0.02$ & $33 \pm 0.32$ \\
\hline & & Etoa & $14.4 \pm 0.37$ & $17 \pm 0.03$ & $35 \pm 0.21$ \\
\hline \multirow[b]{3}{*}{5} & \multirow[b]{3}{*}{ Orthosiphon staminus } & Meoh & $16.6 \pm 0.65$ & $24 \pm 0.03$ & $48 \pm 0.36$ \\
\hline & & Water & $13.7 \pm 0.32$ & $19 \pm 0.05$ & $22 \pm 0.56$ \\
\hline & & Etoa & $9.2 \pm 0.45$ & $13 \pm 0.07$ & $17 \pm 0.87$ \\
\hline
\end{tabular}


In-vitro Antioxidant and Antimicrobial...

Table-2. Anti bacterial activity of collected plant extracts against toxigenic and pathogenic bacteria.

\begin{tabular}{|c|c|c|c|c|c|c|c|c|c|c|c|c|c|c|}
\hline \multirow{2}{*}{$\begin{array}{l}\text { S.N } \\
0 \\
\end{array}$} & \multirow{2}{*}{ Plant Name } & \multirow[b]{2}{*}{ Extract } & \multicolumn{12}{|c|}{ Minimum inhibition concentrations $(\mu \mathrm{g} / \mathrm{ml})$} \\
\hline & & & S.a & B.c & E.c & K.p & S.f & P.a & S.t & A.h & $\mathbf{P . v}$ & L.m & V.c & V.p \\
\hline \multirow{3}{*}{1} & \multirow{3}{*}{$\begin{array}{l}\text { Naravelia } \\
\text { zeylanica DC. }\end{array}$} & Meoh & 56 & 56 & 28 & 56 & 224 & 448 & 112 & 112 & 28 & 14 & 14 & 14 \\
\hline & & Water & 56 & 112 & 56 & 112 & 112 & 448 & 448 & 448 & 56 & 28 & 28 & 56 \\
\hline & & Etoa & 56 & 56 & 56 & 56 & 224 & 448 & 224 & 224 & 28 & 28 & 28 & 56 \\
\hline \multirow{3}{*}{2} & \multirow{3}{*}{$\begin{array}{l}\text { Adhathoda } \\
\text { zeylanica } \\
\text { Medic. }\end{array}$} & Meoh & 28 & 112 & 28 & 28 & 28 & 56 & 112 & 224 & 28 & 56 & $\mathrm{Nd}$ & $\mathrm{Nd}$ \\
\hline & & Water & $\mathrm{Nd}$ & $\mathrm{Nd}$ & 112 & $\mathrm{Nd}$ & 56 & $\mathrm{Nd}$ & $\mathrm{Nd}$ & 56 & 112 & $\mathrm{Nd}$ & 448 & 112 \\
\hline & & Etoa & 56 & 112 & 28 & 56 & $\mathrm{Nd}$ & $\mathrm{Nd}$ & 224 & 896 & 112 & 112 & 56 & 112 \\
\hline \multirow{3}{*}{3} & \multirow{3}{*}{$\begin{array}{l}\text { Cassia } \\
\text { auriculata } L .\end{array}$} & Meoh & 28 & 56 & 56 & 56 & 56 & 56 & 56 & 56 & 56 & 14 & 28 & 14 \\
\hline & & Water & 112 & 112 & 56 & 56 & 224 & 224 & 224 & 448 & 112 & 56 & $\mathrm{Nd}$ & 28 \\
\hline & & Etoa & 56 & 112 & 56 & 56 & 112 & 112 & 224 & 448 & 56 & 28 & 112 & 28 \\
\hline \multirow{3}{*}{4} & \multirow{3}{*}{$\begin{array}{l}\text { Vitex negundo } \\
\text { L. }\end{array}$} & Meoh & 224 & 224 & 896 & 28 & $\mathrm{Nd}$ & $\mathrm{Nd}$ & $\mathrm{Nd}$ & 112 & 448 & $\mathrm{Nd}$ & 56 & 56 \\
\hline & & Water & 448 & 896 & $\mathrm{Nd}$ & 112 & $\mathrm{Nd}$ & $\mathrm{Nd}$ & 448 & $\mathrm{Nd}$ & $\mathrm{Nd}$ & $\mathrm{Nd}$ & 224 & 112 \\
\hline & & Etoa & ND & 448 & 448 & 112 & $\mathrm{Nd}$ & $\mathrm{Nd}$ & $\mathrm{Nd}$ & 224 & $\mathrm{Nd}$ & 112 & 56 & 112 \\
\hline \multirow{3}{*}{5} & \multirow{3}{*}{$\begin{array}{l}\text { Orthosiphon } \\
\text { staminus }\end{array}$} & Meoh & 112 & 112 & 896 & 112 & 56 & Nd & 112 & 112 & 112 & 56 & 56 & 56 \\
\hline & & Water & $\mathrm{Nd}$ & 896 & 448 & $\mathrm{Nd}$ & 448 & $\mathrm{Nd}$ & 448 & $\mathrm{Nd}$ & 224 & $\mathrm{Nd}$ & 112 & 112 \\
\hline & & Etoa & 224 & 448 & $\mathrm{Nd}$ & 224 & 896 & $\mathrm{Nd}$ & 224 & 224 & 448 & $\mathrm{Nd}$ & 56 & 112 \\
\hline
\end{tabular}

Note: S.a: Staphylococcus aureus; B.c: Bacillus cereus; E.c: Escherichia coli; K.p: Klebsiella pneumonia; S.f: Shigella flexneri; P.a: Pseudomonas aeruginosa; S.t: Salmonellal typhimurium; A.h: Aeromans hydrophila; P.v: Proteus vulgaris; L.m: Listeria monocytogenis; V.c: Vibrio cholera; V.p: vibrio parahaemolyticus. Nd-Not detected activity.

Table-3. Anti fungal activity of collected plant extracts against pathogenic and toxigenic fungi.

\begin{tabular}{|c|c|c|c|c|c|c|c|c|c|c|c|c|c|c|}
\hline \multirow{2}{*}{$\begin{array}{l}\text { S. } \\
\text { No }\end{array}$} & \multirow{2}{*}{$\begin{array}{l}\text { Plant } \\
\text { Name }\end{array}$} & \multirow[b]{2}{*}{ Extract } & \multicolumn{12}{|c|}{ Minimum inhibition concentrations $(\mu \mathrm{g} / \mathrm{ml})$} \\
\hline & & & A.f & A.p & A.n & A.0 & P. v & P.n & P.e & F.g & F.s & F.o & F.s & C.a \\
\hline \multirow[t]{3}{*}{1} & \multirow{3}{*}{$\begin{array}{l}\text { Naravelia } \\
\text { zeylanica } \\
\text { DC. }\end{array}$} & Meoh & 320 & 640 & 640 & Nd & Nd & Nd & Nd & 640 & 320 & 1000 & 640 & 320 \\
\hline & & Water & Nd & Nd & Nd & Nd & Nd & Nd & Nd & Nd & Nd & Nd & Nd & 320 \\
\hline & & Etoa & 320 & 640 & 160 & 320 & 160 & $\mathrm{Nd}$ & Nd & 320 & 320 & 1000 & 1000 & 320 \\
\hline \multirow[t]{3}{*}{2} & \multirow{3}{*}{$\begin{array}{l}\text { Adhathoda } \\
\text { zeylanica } \\
\text { Medic. }\end{array}$} & Meoh & 160 & 320 & 160 & 80 & 640 & $\mathrm{Nd}$ & 640 & 320 & 320 & 320 & 640 & 160 \\
\hline & & Water & 640 & $\mathrm{Nd}$ & $\mathrm{Nd}$ & $\mathrm{Nd}$ & 1000 & $\mathrm{Nd}$ & Nd & 640 & 640 & Nd & 1000 & 640 \\
\hline & & Etoa & 1000 & 640 & 320 & 320 & 1000 & 160 & 640 & 1000 & 640 & 640 & 1000 & 320 \\
\hline \multirow[t]{3}{*}{3} & \multirow{3}{*}{$\begin{array}{l}\text { Cassia } \\
\text { auriculata } \\
\text { L. }\end{array}$} & Meoh & 80 & 160 & 160 & 80 & 80 & 160 & 160 & 320 & 160 & 160 & 160 & 40 \\
\hline & & Water & 320 & 640 & 1000 & $\mathrm{Nd}$ & $\mathrm{Nd}$ & $\mathrm{Nd}$ & $\mathrm{Nd}$ & 320 & 320 & 160 & 320 & 320 \\
\hline & & Etoa & 320 & $\mathrm{Nd}$ & 320 & $\mathrm{Nd}$ & 320 & 1000 & $\mathrm{Nd}$ & 320 & 320 & 320 & 160 & $\mathrm{Nd}$ \\
\hline \multirow[t]{3}{*}{4} & \multirow{3}{*}{$\begin{array}{l}\text { Vitex } \\
\text { negundo } \\
\text { L. }\end{array}$} & Meoh & $\mathrm{Nd}$ & $\mathrm{Nd}$ & $\mathrm{Nd}$ & $\mathrm{Nd}$ & $\mathrm{Nd}$ & $\mathrm{Nd}$ & $\mathrm{Nd}$ & 160 & 640 & 640 & 1000 & 160 \\
\hline & & Water & $\mathrm{Nd}$ & $\mathrm{Nd}$ & $\mathrm{Nd}$ & $\mathrm{Nd}$ & $\mathrm{Nd}$ & $\mathrm{Nd}$ & $\mathrm{Nd}$ & $\mathrm{Nd}$ & $\mathrm{Nd}$ & $\mathrm{Nd}$ & $\mathrm{Nd}$ & $\mathrm{Nd}$ \\
\hline & & Etoa & 640 & 1000 & 320 & 1000 & $\mathrm{Nd}$ & $\mathrm{Nd}$ & Nd & $\mathrm{Nd}$ & $\mathrm{Nd}$ & $\mathrm{Nd}$ & $\mathrm{Nd}$ & 640 \\
\hline \multirow[t]{3}{*}{5} & \multirow{3}{*}{$\begin{array}{l}\text { Orthosiph } \\
\text { on } \\
\text { staminus }\end{array}$} & Meoh & 160 & 640 & $\mathrm{Nd}$ & 640 & 320 & 320 & 320 & 320 & 320 & Nd & 640 & 160 \\
\hline & & Water & $\mathrm{Nd}$ & $\mathrm{Nd}$ & $\mathrm{Nd}$ & $\mathrm{Nd}$ & $\mathrm{Nd}$ & $\mathrm{Nd}$ & $\mathrm{Nd}$ & $\mathrm{Nd}$ & $\mathrm{Nd}$ & $\mathrm{Nd}$ & $\mathrm{Nd}$ & $\mathrm{Nd}$ \\
\hline & & Etoa & $\mathrm{Nd}$ & 640 & 640 & 1000 & 1000 & 640 & 640 & $\mathrm{Nd}$ & 640 & 640 & 1000 & 320 \\
\hline
\end{tabular}

Note: A.f: Aspergillus flavus; A.p: A. paraciticus; A.n: A. niger; A.o: A. ochraceus; P.v: Penicillium verrucosum; P.n: P. norodicum; P.e: P. expansum; F.g: Fusarium graminearum; F.s: $F$. solani; F.v: $F$. verticillioides; F.o: F. oxysporum; F.s: F. sprorotrichioides; C.a: Candida albicans. Nd-Not detected activity 
Figure-1: DPPH activity of selected medicinal plant extracts
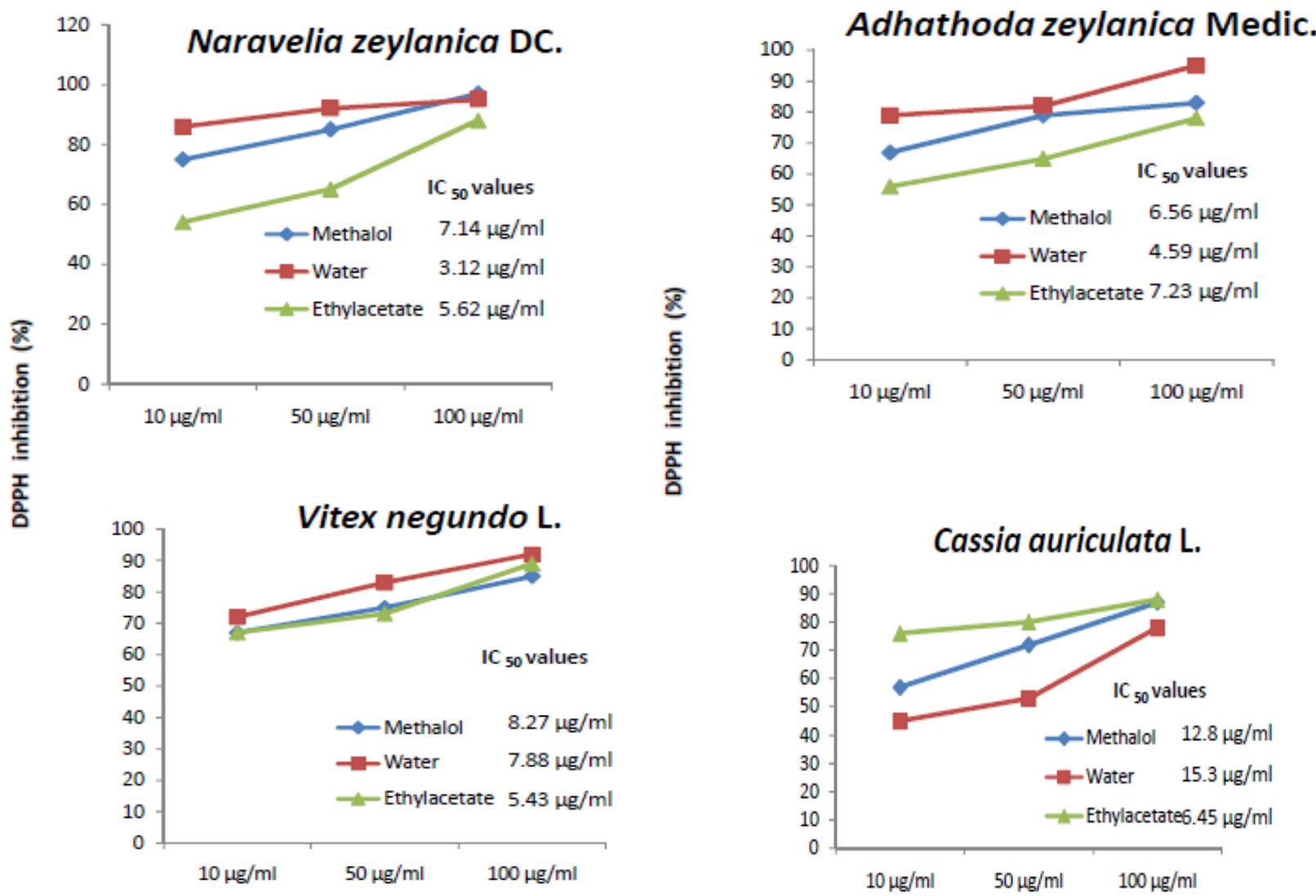

\section{Orthosiphon diffusus}

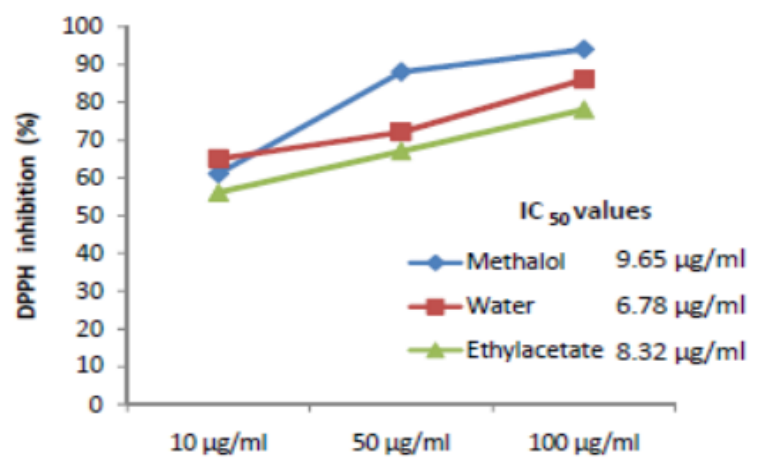

\section{DISCUSSION}

Plants are an important source of potentially useful structures for the development of new chemotherapeutic agents. According to the ethnobotanical survey conducted by our institute jointly with ICMR in the Western Ghat regions of India, 500 medicinal plants were identified with medicinal importance for the treatment of various diseases. Among, Naravelia zeylanica DC. (Ranunculaceae),Adhathoda zeylanica Medic. (Acanthaceae), Cassia auriculata L. (Fabaceae), Vitex negundo L. (Verbenaceae) and Orthosiphon staminus (Lamiaceae) are of primary importance and have efficient capability to treat maximum number of diseases. Phenolic compounds are a class of antioxidant agents which act as free radical scavengers and are considered as a major group of compounds that contribute to the antioxidant activities of plant materials because of their neutralizing ability on free radicals due to their hydroxyl groups [40]. Flavonoids are a group of polyphenolic 
compounds with known properties of free radical scavenging, antibacterial and anti-inflammatory action [41]. It is well-known that phenolic compounds contribute to quality and nutritional value in terms of modifying color, taste, aroma, flavor and also in providing health beneficial effects. The present results showed that the selected medicinal plant extracts are rich in total phenol and flavanoid contents (Table-1). In the present study, all the fifteen plant extracts showed higher phenolic contents i.e. $9 \%$ to $27 \%$ of dry weight. However, the flavanoid content showed lower when compared to the total phenolics (Table-1). The results of the present study report that the methanolic extracts have more phenolic and flavanoid and then followed by ethylaceate extract in all studied plant samples.

Since it is now recognized that there is no single test to evaluate antioxidant activities of the compounds with wide spectra of structures, modes of action, and physical and chemical properties [42], two different assays were employed as a part of our investigation. DPPH (2,2-diphenyl-1-picrylhydrazyl) is a stable radical and is often used in assessment of the antioxidant activity. The free radical DPPH possesses a characteristic absorption at $517 \mathrm{~nm}$ (purple in color), which decreases significantly when exposed to radicalscavengers (due to hydrogen atoms transfer from antioxidant to DPPH) [43]. The activity observed is in a very good correlation with the composition, where the most active extracts are those rich in polyphenol and flavonoids (Fig-1; Table-1).

Plants are important source of potentially useful structures for the development of new chemotherapeutic agents. The first step towards this goal is the in vitro antibacterial activity assay [44]. Many reports are available on the antiviral, antibacterial, antifungal, anthelmintic, antimolluscal and anti-inflammatory properties of plants [45, 46]. Some of these observations have helped in identifying the active principle responsible for such activities and in the developing drugs for the therapeutic use in human beings. However, not many reports are available on the Plant-based antimicrobials having enormous therapeutic potential as they can serve the purpose with lesser side effects that are often associated with synthetic antimicrobials [47]. The potential for developing antimicrobials from higher plants appears rewarding as it will lead to the development of a phytomedicine to act against microbes. The different extracts possessed different inhibitory activities against different bacterial and fungal strains (Table-2 \& Table-3). The pattern of inhibition varied with plant extract, solvent used for extraction and microorganism tested. The antimicrobial activity of extracts obtained from Naravelia zeylanica DC. showed potent activity against all the bacterial strains and the methanolic extract of the same plant showed active against all studied fungal pathogens. The results of present investigation clearly indicate that the antibacterial and antifungal activity vary with the species of the plants and extract used.

\section{CONCLUSION}

From the present study it can ne concluded that the antioxidant activity observed is in a very good correlation with the selected medicinal plant extracts. Also it was clearly evident that the five Indian Medicinal plants showed potent antimicrobial activity. Thus, the study ascertains the value of plants used in ethanobotany by the locals, which could be of considerable interest to the development of new drugs.

\section{References}

[1]. E. Middleton, C. Kandaswami, and T. C. Theoharides, The effects of plant flavonoids on mammalian cells: Implications for inflammation, heart disease and cancer, Pharmacological Reviews, 52(4), 2001, 673-751.

[2]. D. Amic, D. Davidovic-Amic, D. Beslo, and N. Trinajstic, Structure-radical scavenging activity relationship of flavonoids, Croatica Chemica Acta, 76(1), 2003, 55-61.

[3]. K. Alpinar, M. Ozyurek, U. Kolak, K. Guclu, C. Aras, M. Altun, S. E. Celik, K. I. Berker, B. Bektasoglu, and R. Apak, Antioxidant Capacities of Some Food Plants Wildly Grown in Ayvalik of Turkey, Food Science and Technology Research, 15(1), 2009, 59-64.

[4]. I. S. Young, and J. V. Woodside, Antioxidants in health and disease, Journal of Clinical Pathology, 54(3), 2001, 176-186.

[5]. B. Halliwell, Free radicals, antioxidants, and human disease: curiosity, cause, or consequence? Lancet. 344(8924), 1994, 721724.

[6]. P. D. Duh, Y. Y. Tu, and G. C. Yen, Antioxidant activity of aqueous extract of Harnjyur (Chrysanthemum morifolium Ramat), Lebensmittel-Wissenschaft \& Technologie. 32, 1999, 269-277.

[7]. R. Sudararajan, N. A. Haja, K.Venkatesan, K. Mukherjee, B. P. Saha, A. Bandyopadhyay, and P. K. Mukherjee, Cytisus scoparius Link- A natural antioxidant, BMC Complementary and Alternative Medicine, 6, 2006, 1-7.

[8]. O. I. Aruoma, Free radicals, oxidative stress and antioxidants in human health and disease, Journal of the American Oil Chemists Society, 75(2), 1998, 199-212.

[9]. D. J. Lefer, and D. N. Granger, Oxidative stress and cardiac disease, American Journal of Medicine, 109(4), $2000,315-323$.

[10]. M. A. Smith, C.A. Rottkamp, A. Nunomura, A.K. Raina, and G. Perry, Oxidative stress in Alzheimer's disease, Biochimica et Biophysica Acta, 1502(1), 2000, 139-144.

[11]. S. Bhatia, R. Shukla, S.V. Madhu, J. K. Gambhir, and K. M. Prabhu, Antioxidant status, lipid peroxidation and nitric oxide end products in patients of type 2 diabetes mellitus with nephropathy, Clinical Biochemistry, 36(7), 2003, 557-562.

[12]. E. Peuchant, J. L. Brun, V. Rigalleau, L. Dubourg, M. J. Thomas, J. Y. Daniel, J. J. Leng, H. Gin, Oxidative and antioxidative status in pregnant women with either gestational or type 1 Diabetes, Clinical Biochemistry, 37(4), 2004, $293-298$.

[13]. P. Steer, J. Milligard, D. M. Sarabi, S. Basu, B. Vessby, T. Kahan, M. Edner, and L. Lind, Cardiac and vascular structure and function are related to lipid peroxidation and metabolism, Lipids 37(3), 2002, 231-236.

[14]. K. Uchida, Role of reactive aldehyde in cardiovascular diseases, Free Radical Biology and Medicine, 28(12), 2000, $1685-1696$. 
[15]. M. Gerber, M. C. Boutron-Ruault, S. Hercberg, E. Riboli, A. Scalbert, and M. H. Siess, Food and Cancer: state of the art about the protective effect of fruits and vegetables, Bulletin du Cancer, 89(3), 2002, 293-312.

[16]. V. Di Matteo, and E. Esposito, Biochemical and therapeutic effects of antioxidants in the treatment of Alzheimer's disease, Parkinson's disease, and amyotrophic lateral sclerosis, Current Drug Targets. CNS and Neurological Disorders, 2(2), 2003, 95107.

[17]. N. Sreejayan, and M. N. A. Rao, Free radical scavenging activity of Curcuminoids, Arzneimittel-Forschung/Drug Research, 46(2), 1996, 169-171.

[18]. P. Knekt, R. Jarvinen, A. Reunanen, and J. Maatela, Flavonoid intake and coronary mortality in Finland: A cohort study, British Medical Journal, 312(7029), 1996, 478-481.

[19]. H. Sies, Strategies of antioxidant defense, European Journal of Biochemistry, 215(2), 1993, $213-219$.

[20]. C. C. Wong, H. B. Li, K. W. Cheng, and F. Chen, A systematic survey of antioxidant activity of 30 Chinese medicinal plants using the ferric reducing antioxidant power assay, Food Chemistry, 97(4), 2006, 705-711.

[21]. K. T. Chung, T. Y. Wong, C. I. Wei, Y. W. Huang, and Y. Lin, Tannins and human health: A review, Critical Reviews in Food Science and Nutrition, 38(6), 1998, 421-464.

[22]. Y. Cai, Q. Luo, M. Sun, and H. Corke, Antioxidant activity and phenolic compounds of 112 traditional Chinese medicinal plants associated with anticancer, Life Sciences, 74(17), 2004, 2157-2184.

[23]. A. Djeridane, M. Yousfi, B. Nadjemi, D. Boutassouna, P. Stocker, and N. Vidal, Antioxidant activity of some Algerian medicinal plants extracts containing phenolic compounds, Food Chemistry, 97(4), 2006, 654-660.

[24]. R. Giordani, J. Trebaux, M. Masi, and P. Regli, Enhanced antifungal activity of ketoconazole by Euphorbia characias latex against Candida albicans, Journal of Ethnopharmacology. 78(1), 2001, 1-5.

[25]. J. M. Fostel, and P. A. Lartey, Emerging novel antifungal agents, Drug Discovery Today, 5(1), $2000,25-32$.

[26]. P. B. de Carvalho, and E. I. Ferreira, Leishmaniasis phytotherapy. Nature's leadership against an ancient disease, Fitoterapia, 72(6), 2001, 599-618.

[27]. O. Kayser, and A. F. Kiderlen, In vitro leishmanicidal activity of naturally occurring chalcones, Phytotherapy Research. 15(2), 2001, 148-52.

[28]. P. R. Tharkar, A. U. Tatiya, P. R. Shinde, S. J. Surana, and U. K. Patil, Antifungal activity of Glycyrrhiza glabra Linn. and Emblica officinalis Gaertn. by Direct bioautography method, International Journal of PharmTech Research, 2(2), 2010, 15471549.

[29]. S. K. Gupta, and A. B. Banerjee, Screening of selected West Bengal plants for antifungal activity, Economic Botany, 26(3), 2008, 255-259.

[30]. M. Suresh, P. K. Rath, A. Panneerselvam, D. Dhanasekaran, and N. Thajuddin, Antifungal activity of selected Indian medicinal plant salt, Journal of Global Pharma Technology, 2(4), 2010, 71-74.

[31]. J. Parekh, and S. Chanda, In vitro antifungal activity of methanol extracts of some Indian medicinal plants against pathogenic yeast and moulds, African Journal of Biotechnology, 7(23), 2008, 4349-4353

[32]. M. Patel, and M. M. Coogan, Antifungal activity of the plant Dodonaea viscosa var. angustifolia on Candida albicans from HIVinfected patients, Journal of Ethnopharmacology, 118(1), 2008, 173-176.

[33]. T. R. Govindachari, G. Suresh, G. Gopalakrishnan, B. Balaganesan, and S. Masilamani, Identification of antifungal compounds from the seed oil of Azadirachta indica, Phytoparasitica. 26(2), 1998, 109-116.

[34]. D. Srinivasan, S. Nathan, T. Suresh, and P. Lakshmana Perumalsamy, Antimicrobial activity of certain Indian medicinal plants used in folkloric medicine, Journal of Ethnopharmacology, 74(3), 2001, 217- 220.

[35]. V. Duraipandiyan, S. Ignacimuthu, and M. Gnanasekaran, Antifungal activity of triterpenoid isolated from Azima tetracantha leaves, Folia Histochem Cytolbia, 48(26), 2010, 311-313.

[36]. D. O. Kim, O. K. Chun, Y. J. Kim, H. Y. Moon, and C. Y. Lee, Quantification of polyphenolics and their antioxidant capacity in fresh plums, Journal of Agricultural and Food Chemistry, 51(22), 2003, 6509-6515.

[37]. J. Zhishen, T. Mengcheng, and W. Jianming, The determination of flavonoid contents in mulberry and their scavenging effects on superoxide radicals, Food Chemistry, 64(4), 1999, 555-559.

[38]. I. I. Koleva, T. A. Van Beek, J. P. H. Linssen, A. de Groot, and L. N. Evstatieva, Screening of plant extracts for antioxidant activity: a comparative study on three testing methods, Phytochemical Analysis, 13(1), 2002, 8-17.

[39]. J. Kim, M. R. Marshall, and C. I. Wei, Antibacterial activity of some essential oil components against five food borne pathogens, Journal of Agricultural and Food Chemistry, 43(11), 1995, 2839 -2845.

[40]. A. D. Richard, and M. P. Giulio, Flavonoids and Isoflavonoids: From Plant Biology to Agriculture and Neuroscience, Plant Physiology, 154(2), 2010, 453-57.

[41]. A. Cassidy, E. J. O’Reilly, C. Kay, L. Sampson, M. Franz, J. P. Forman, G. Curhan, and E. B. Rimm, Habitual intake of flavonoid subclasses and incident hypertension in adults, American Journal of Clinical Nutrition, 93(2), 2011,338 -347.

[42]. R. Apak, K. Guçlu, B. Demirata, M. Ozyurek, S. E. Çelik, B. Bektasoglu, K.I. Berker, and D. Ozyurt, Comparative Evaluation of Various Total Antioxidant Capacity Assays Applied to Phenolic Compounds with the CUPRAC Assay, Molecules, 12(7), 2007, 1496-1547.

[43]. C. Sanchez-Moreno, Methods used to evaluate the free radical scavenging activity in foods and biological systems, Food Science and Technology International, 8(3), 2002, 121-137.

[44]. L. Tona, K. Kambu, N. Ngimbi, K. Cimanga, and A. J. Vlietinck, Antiamoebic and phytochemical screening of some Congolese medicinal plants, Journal of Ethnopharmacology, 61, 1998, 57-65.

[45]. R. P. Samy, and S. Ignacimuthu, Antibacterial activity of some folklore medicinal plants used by tribals in Western Ghats in India, Journal of Ethnopharmacology, 69(1), 2000, 63-71.

[46]. E. A. Palombo, and S. J. Semple, Antibacterial activity of traditional Australian medicinal plants, Journal of Ethnopharmacology, 77(2-3), 2001, 151-157.

[47]. M. W. Iwu, A. R. Duncan, and C. O. Okunji, New antimicrobials of plant origin. In: Janick J. ed. Perspectives on New Crops and New Uses, Alexandria, VA: ASHS Press, 1999. pp. 457-462. 